\title{
原子炉構造物の熱疲労に関する研究の現状と課題*
}

\author{
笠原 直人 ${ }^{* 1}$ ，林 眞琴*2

\section{Study and Perspectives on High Cycle Thermal Fatigue in Nuclear Power Plants}

\author{
Naoto KASAHARA and Makoto HAYASHI ${ }^{* 2}$ \\ ${ }^{* 2}$ Ibaraki Prefectural Government, Planning Division \\ 162-1, Shirakata, Tokai-mura, Ibaraki, 319-1106 Japan
}

\begin{abstract}
Various kinds of thermal fatigue failure modes exist in nuclear power plant components. Main causes of thermal loads are structural responses to fluid temperature changes. These phenomena have complex mechanisms and so many patterns, that their problems still occur even though well-known issues. Among them, this paper treats high cycle thermal fatigue of branch pipes as the typical mode. Firstly, experimental and analytical researches are explained for thermal load evaluation. Through them, both numerical and kinematic methods were developed. Next chapter describes thermal fatigue strength studies on both crack initiations and propagations. They revealed the similarities of thermal crack initiations with mechanical ones and frequency characteristics of crack propagation. Finally, current status and future challenges are discussed for evaluation of actual plants.
\end{abstract}

Key Words : Thermal Fatigue, Thermal Hydraulic, Thermal Stress, Crack Initiation, Crack Propagation, Nuclear Components

\section{1. 緒言}

\section{$1 \cdot 1$ 原子炉構造物の熱疲労破損}

原子力プラントの熱疲労は古くから認識されている課題であるが，近年においても破損例が報告され続けてい $ろ^{(1)-(3)}$. その理由として, 熱疲労の発生原因がプラント中で生じる冷却材の温度変動であることから, 現象が熱 流動と構造の両分野に亘る複雑なものであり, 運転中に生じる様々な熱流動現象に応じて多くのモードが存在す ることが挙げられる. また, 破損に至るメカニズムは, 冷却材の温度摇らぎが構造物の熱応力の変動に変換され, 熱応力の繰り返しが材料の疲労破損を引き起こすという過程から成ることから, その予測には, 流体, 構造, 材 料の各学術領域の知識の連携が必要となる. 本論文は原子炉構造物の熱疲労に関する研究の現状と課題を概説す る.

これまでの国内外の原子力配管で実際に生じた熱疲労の損傷事例により, 熱疲労モードを整理した結果を図 1 に示す. 熱疲労につながる冷却材の温度変化は熱荷重の発生原因に基づき大きく分けると,「温度摇らぎ」「熱成 層化」および「系統全体の熱過渡」とその他に分類される．さらに「温度摇らぎ」は不規則温度変動型とホット スポット型に, 「熱成層化」はその発生要因により, キャビティフロー型熱成層, 運転操作型熱成層, 并グランド リーク型熱成層及び弁シートリーク型熱成層に細分される。ここで，材料強度の観点からは疲労破損様式は塑性 変形を考慮する必要のある概ね $10^{4} \sim 10^{5}$ サイクルより少ない繰り返し回数で破損が生じる低サイクル疲労と, そ れより多い繰り返し回数で破損する高サイクル疲労に分類される.これに対し, 原子力分野ではプラントの起動 停止に伴う数百回オーダの繰り返しとなる系統熱過渡の場合に低サイクル疲労を想定し，それ以外の熱荷重に対 しては幅広い繰り返し数があるものの慣例として高サイクル熱疲労と呼んでいることから，ここではこれらの慣

* 原稿受付 2012 年 2 月 9 日

*1 正員, 東京大学 (T160-0016 東京都文京区本郷 3 丁目)

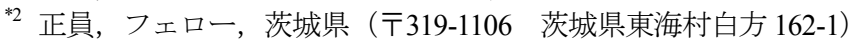

E-mail:kasa@ju-tokyo.ac.jp 


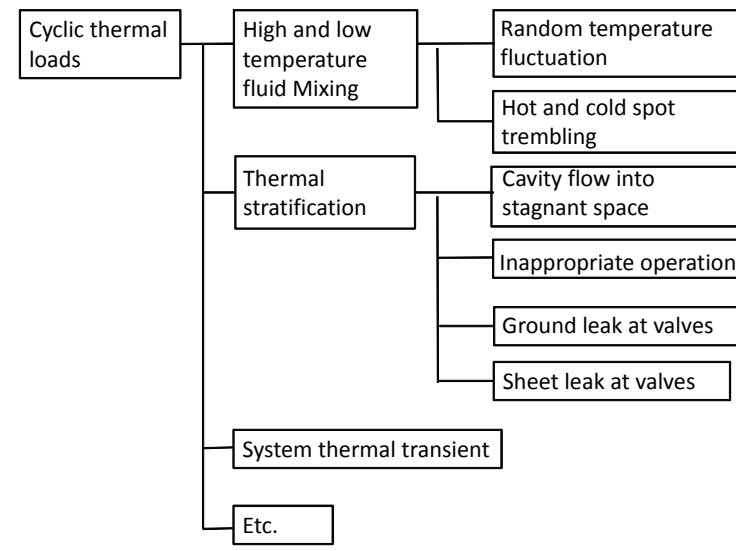

Fig.1 Classification of thermal loads for fatigue failure.

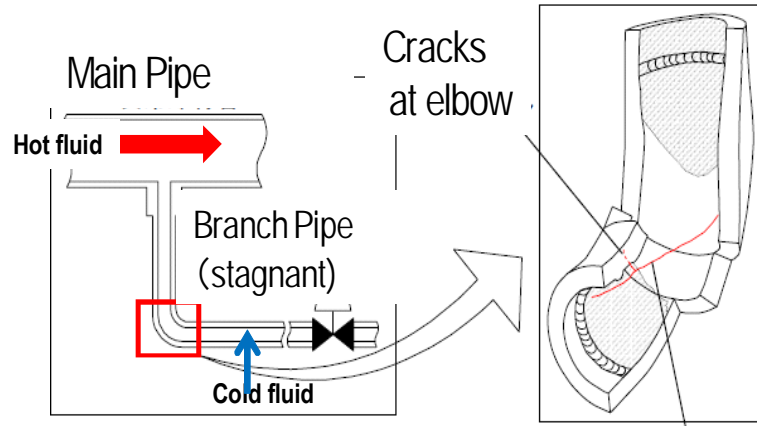

Fig.3 Thermal fatigue crack caused by temperature stratification at stagnant branch pipe in PWR.

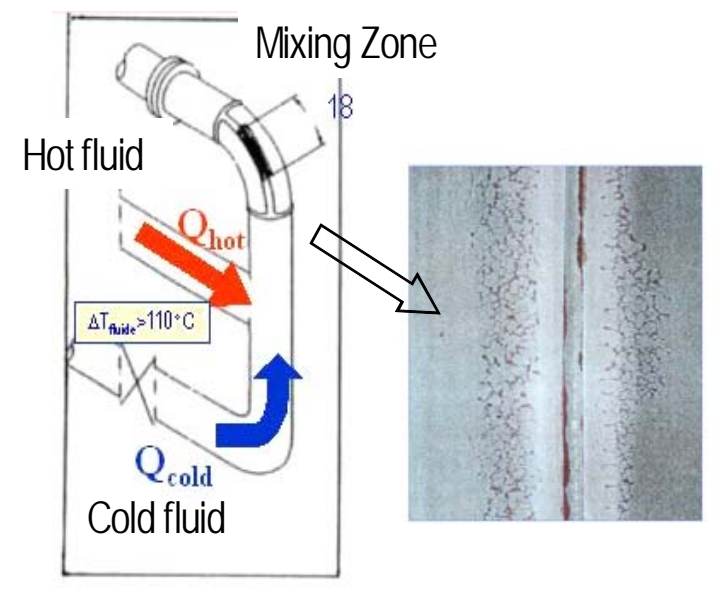

Fig. 2 High cycle thermal fatigue crack caused by temperature fluctuation at mixing zone between cold and hot fluid.observed in PWR.

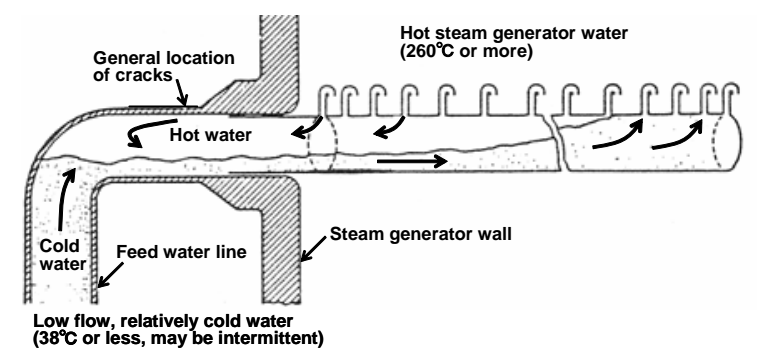

Fig.4 Thermal fatigue crack initiation at feed water inlet nozzle of steam generator caused by thermal stratification.

例に従った表現を用いる. 図 1 の破損モードの中で, 特に図 2 と図 3 に示寸「不規則温度変動による高サイクル 熱疲労」と「閉塞分岐管停留部の熱成層化による高サイクル熱疲労」について，その発生頻度と対策の難しさか ら評価法整備の優先度が高いと判断され, これらの熱疲労モードについては特に詳しく研究され日本機械学会,

“配管の高サイクル熱疲労に関する評価指針”（以下 JSME 指針）()が整備された.

図 4 に米国 PWR の蒸気発生器の給水ノズルにおける熱成層に起因する熱疲労き裂の発生状況を示寸．給水配 管が蒸気発生器に入った部分においては, 約 $260^{\circ} \mathrm{C}$ 高温水が上部に滞留している. 給水配管には約 $38^{\circ} \mathrm{C} の$ 低温 水が供給されるが，この低温水は間欠的に供給されるため, 給水ノズル部周辺は高温水と低温水に交互に曝され る結果, 熱疲労き裂が発生する.

弁シートリークによる熱成層型では，九州電力玄海 1 号機の残留熱除去系の入口隔離弁において熱疲労き裂が 貫通し, 微少な冷却材の漏洩に至ったことがある. 入口隔離弁グランド部からのリークにより, 通常低温水が滞 留している水平配管の上部に 1 次冷却系からの高温水が流入する. その結果, 弁体の膨張によりシート部の間隙 が小さくなってグランド漏れが少なくなり, 再度弁体の冷却により間隙が大きくなって, グランド漏れが増加す る.これが繰返されることにより隔離弁の上流側の配管エルボ部における溶接頂部で熱疲労き裂が発生した.

日本原子力発電敦賀 2 号機の再生熱交換器において, 内筒によって高低温水の熱成層が形成され（低温の主流 は約 $170^{\circ} \mathrm{C}$, 高温のバイパス流は約 $\left.250^{\circ} \mathrm{C}\right)$, さらに支持リングにすき間が形成されて高低温水の流動パターンが 周期的に変動した結果, 出口配管の内面は, 高低温水の混合流による温度変動を受け, 高サイクル熱疲労に至っ た. 図 5 に熱疲労き裂の発生状況を示す. 全部で 12 個のき裂が検出された. き裂は軸方向と周方向に 6 個ずつ 発生しており, 複雑な熱応場であることがうかがわれる. ただし, 周方向き裂はいずれも溶接卜ウ部の応力集 中部に発生しているのが特徴である(5). 


\section{$1 \cdot 2$ 流体温度変動による熱疲労破損の特徵}

不規則温度変動による高サイクル熱疲労を例として, 流体温度変動による熱疲労現象を素過程に分解すると図 6 のようになる．高温と低温の流体が混合すると(A)主流中に温度摇らぎが生じ， (B)境界層内での流体温度摇ら ぎを経て，(C)構造表面での温度摇らぎとなる.この後熱伝導によって (D)構造内の温度摇らぎとなる. これが多 数回繰り返されると $(\mathrm{E})$ 構造表面で疲労き裂が生じ, さらに熱荷重印加が繰り返されるとき裂が進展する. 次に, 各過程における疲労破損一の影響因子を考えてみる. (A) 〜 (D)の過程を構造健全性への影響度の観点から捉える と, 温度摇らぎ振幅の減衰要因が重要となる.これらの各段階における影響因子は図 6 の右側のように(1)主流域 から境界層にかけての対流および乱流混合，(2)粘性底層内部の分子拡散と非定常熱伝達，(3)熱伝導による構造内 部の温度差の緩和と熱ひずみの拘束によるものがある.(E)の段階では(4)多軸性や不規則荷重下の材料特性が影 響する。溶接部・表面粗さ・経年化等による強度低減要因がこれに重畳する.

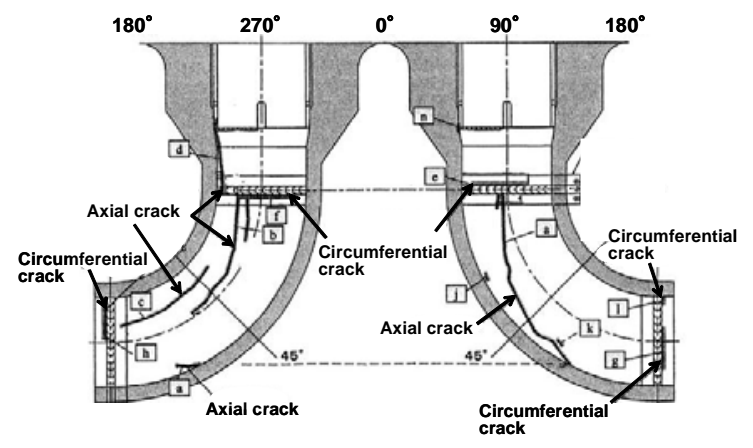

Fig.5 Thermal fatigue crack initiation behavior at outlet nozzle of recovery heat exchanger in Tsuruga No.2 Unit.

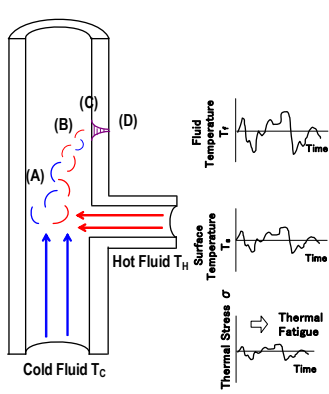

Fig.6 Thermal fatigue failure mechanism by fluid temperature fluctuation.

\section{2. 流体温度変動評価に関する研究}

\section{$2 \cdot 1$ 熱流動試験研究}

原子力分野での熱流動に関連した多くの研究成果が公開されている．また，IAEA ${ }^{(6)}$ や OECD/NEA ${ }^{(7)}$ にり配 管合流部を対象としたベンチマーク解析が行われ, 数多くの参加があった. 国内では日本原子力学会 ${ }^{(8)}$ や日本機 械学会において JSME 指針策定のため, 配管合流部の不規則温度変動に関する多くの熱流動試験研究が行われた ${ }^{(9)}$. 指針では, 試験結果 ${ }^{(10)}$ に基づき図 7 のような合流部の主配管の運動量 $\mathrm{M}_{\mathrm{m}}$ と分岐配管の運動量 $\mathrm{M}_{\mathrm{b}}$ の比によ って流れの状態を分類している，さらに，分類されたそれぞれのパターンに対して，流体温度の時刻歴変動デー タを計測し，振幅と頻度のテーブルやパワースペクトル密度関数を用いた周波数領域で表現した線図が作成され ている. また, 流体温度変動を構造材に受け渡す際に必要となる熱伝達係数を評価するため, 流体温度と構造温 度の同時計測試験が実施されている(11)。

\section{$2 \cdot 2$ CFD の適用性研究}

原子炉構造物を模擬した熱流動試験の課題として, 経費や時間の負担が大きいのみでなく, 熱疲労評価に必要 となる, 詳細な温度変動や, 構造物への熱伝達特性の計測自体が難しいことが挙げられる. これを補う方法とし て, CFD の適用が期待されている.

ここで留意すべき点は, 熱疲労評価に必要なことは, 乱流によって生じる壁近傍の詳細な温度変動の予測であ り，性能評価等で一般的な主流の平均挙動とは CFD 手法への要求条件が異なってくることである.

原子炉の熱疲労評価で必要となる流体問題は一般に Navier-Stokes 方程式で記述され, それを直接離散化した 直接数值シミュレーション DNS が最も高い精度が期待できるが ${ }^{(12)}$ ，膨大な計算時間がかかる．また，商用コード などで一般的なレイノルズ平均モデル RANS は, 平均化操作のために, 疲労評価で必要な細かな温度変動を過小 評価する傾向になる. このため, 現段階でその適用性が有望視されているのは, その中間に位置する Large Eddy Simulation(LES)である. 


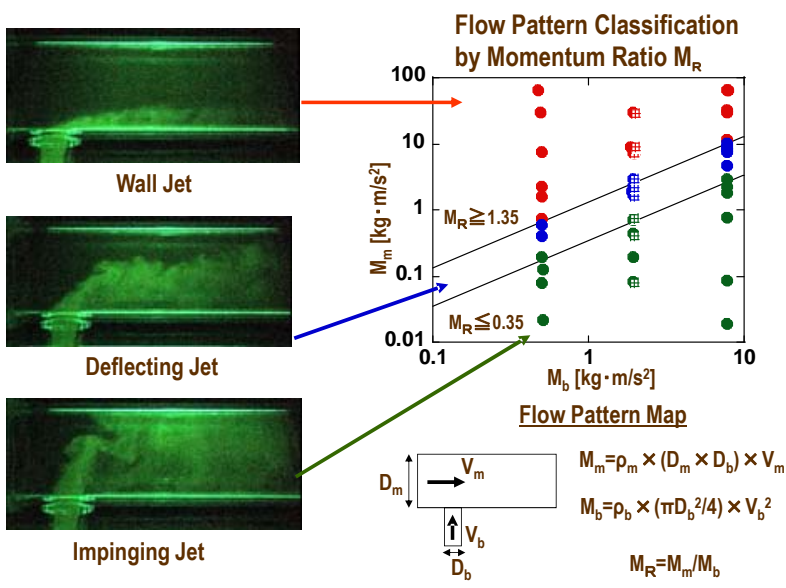

Fig.7 Classification of flow patterns of T-junction by experiments.

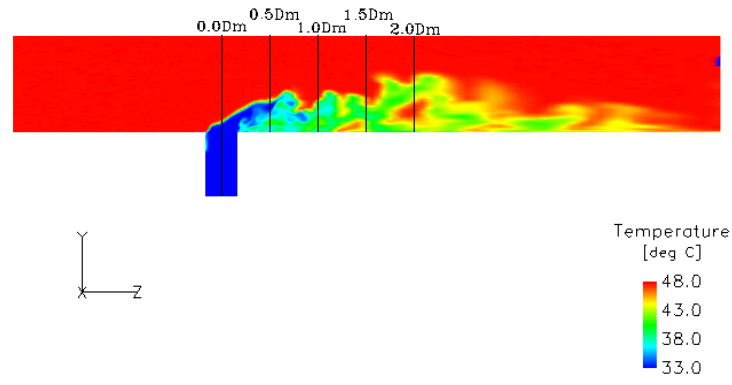

(a) Temperature distribution at $\mathrm{t}=10 \mathrm{~s}$.

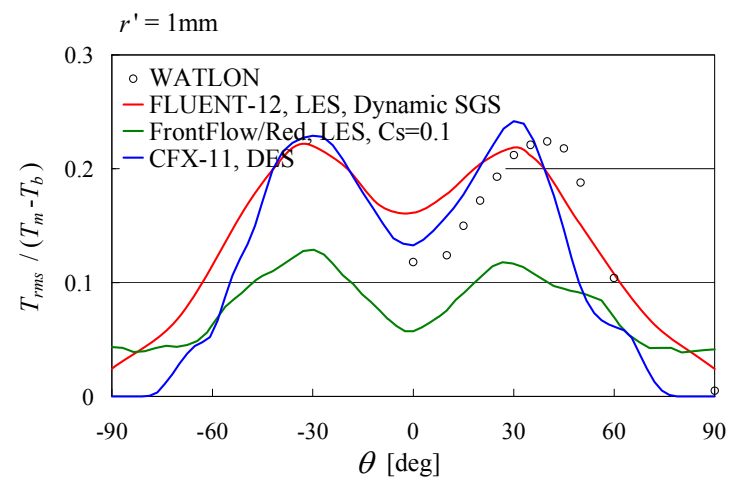

(b) Temperature fluctuation intensity in circumferential direction at $\mathrm{z}=1.0 \mathrm{Dm}$

Fig.8 Benchmark simulation of temperature fluctuation using CFD for the evaluation of the thermal load in a T-junction Pipe.

流体温度変動の再現に対してどのような乱流モデルが適切であるかを調べることは不可欠である．また，壁面 での温度変動が課題となる熱応力評価において，数值解析で壁面の温度分布が十分に再現できているかを調べる ことは, 評価精度の検証のために重要である.さらに, 乱流モデル以外にも計算結果に影響を及ぼす計算条件（解 析格子や差分スキーム）が存在する，例えば数值安定性に優れる低次差分は，人工拡散を導入して温度変動を過 小評価する.

このため, CFD を適用するには，解析コードと用いた条件に対して検証と妥当性確認（Verification and Validation, V\&V）を行うことの重要性が認識されており，国内外でベンチマーク解析が行われている(13)(14).

図 8 はその例である. WATLON 試験結果と，レイノルズ平均(RANS)モデル：SST，BSL-RSM，大規模渦シミ ユレーション (LES) : スマゴリンスキー定数一定 $(\mathrm{Cs}=0)$, Dynamic SGS モデル, 剥離渦シミュレーション(DES) : Strelets モデル (SST ベース)の比較を行ったものである ${ }^{(14)}$.こうした経験を積み重ねることで, V\&V のための 手法とデータを蓄積していくことが今後の課題である.

\section{3. 熱応力評価に関する研究}

\section{$3 \cdot 1 \quad$ 数值解析による方法}

数值解析により熱応力を求める上で最も留意が必要なのは, CFDにより評価された流体温度を構造に伝えて, 構造物中の温度分布を求める方法である. 従来から使用されている一般的方法は，流体温度変動を介して構造物 に熱を伝える方法である. しかし，これを熱疲労評価に適用しようとすると，熱伝達係数が本来非定常な状態に 対して定義されていないことと，流体温度と熱伝達係数が，空間的に分布することが問題となり，大きい目の熱 伝達係数を与えるなどの保守的な方法に頼ることになる.

近年の熱流動数值解析コードでは，流体内の伝熱と構造物中の熱伝導を連成させて解くことにより，配管表面 および内部の温度分布を得る機能を有している．流体と配管の間の熱移動，すなわち熱伝達を数值解析でモデル 化なしに直接求めるためには，流体側の配管表面近傍の計算格子を，境界層を模擬できる程度に非常に小さくす る必要がある．配管表面に隣接する計算格子での流速が零であれば，熱伝導計算により流体から配管への熱流束 を求めることができる。しかし，このような小さい計算格子を用いることは現実的でなく，実際には温度勾配を 


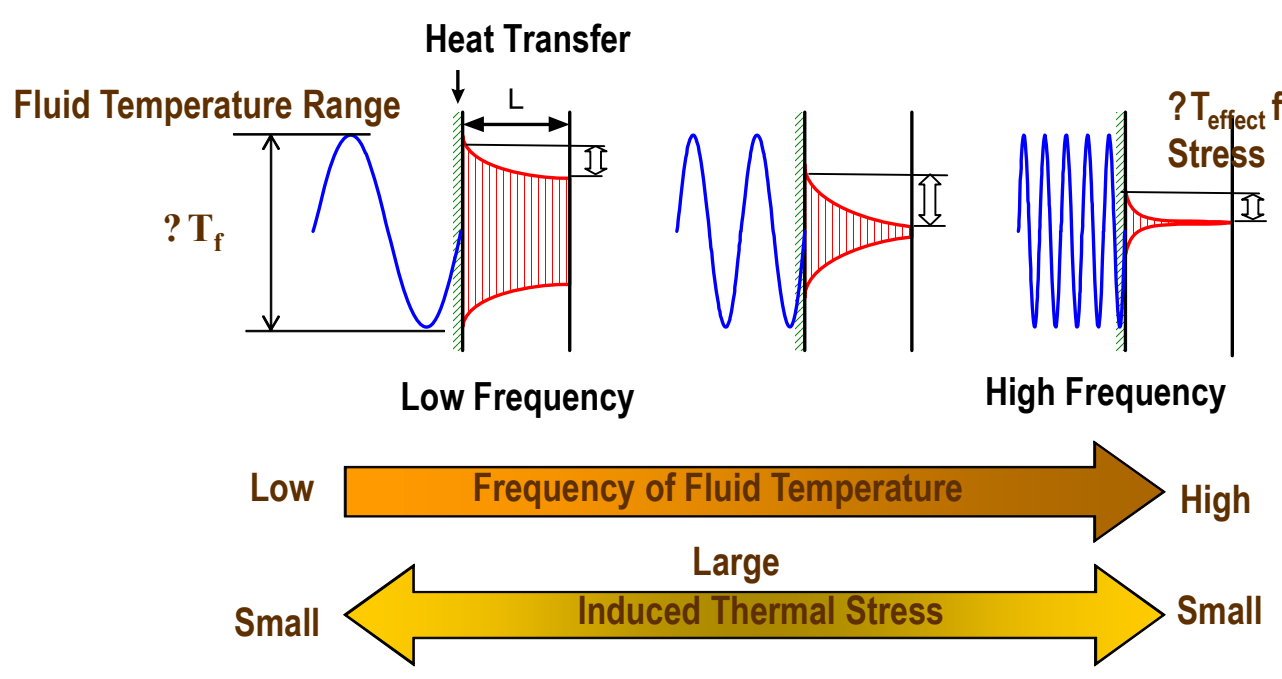

Fig.9 Frequency response characteristics of thermal stress to fluid temperature.

モデル化するなどして，配管への熱伝達を与える必要がある．流体と配管間の熱流束を求める方法として，壁関 数を用いることが考えられる. 壁関数は管壁面近傍における流速分布から，流体から配管への熱流束を仮定する もので，定常な問題に対しては多くの乱流モデルで用いられている．合流配管のような非定常問題に対して必ず しも検証されているわけではないが，近似解法としては有効な方法と考えられる．従って，壁関数，壁面近傍の 格子幅などの計算における壁面の扱いが，熱応力に影響する一つの因子となる.

\section{$3 \cdot 2$ 周波数伝達関数による方法}

流体温度変動に対する熱応力は過渡応答であり，このような応力を特に熱過渡応力(Thermal transient stress) と呼んでいる. 熱過渡応力の大きさは, 流体温度の振幅だけでなく, 温度変化速度にも依存する. 例えば, 図 9 は振幅が同じで，摇らぎの周波数だけが異なる流体温度変動によって生じる板表面の熱応力の応答特性を定性的 に示したものである. ここで，板表面の熱応力は内外面の熱膨張差の相互拘束によって生じることから，その大 きさは板内外面の温度差により規定される. 摇らぎの周波数が高いと, 流体温度の構造材への熱伝達割合は構造 の熱灾答の遅れから低下寸る (伝熱減衰)。逆に周波数が低いと，構造内の熱拡散による均熱化により，熱応力の 要因となる内外面温度差が減少する (構造減衰)。結果として中間の周波数で熱灾力が最大となる.

熱応力の周波数応答特性を定量的に扱ってみる. 簡単化のために実際には板厚方向に連続温度分布を有する板 を, 図 10 に示すような代表温度 $T_{\text {in }}$ で単位体積を有する内面要素と, 代表温度 $T_{\text {out }}$ で単位体積を有する外面要素 の 2 要素の結合で近似する. 本モデルでは流体温度が以下の素過程からなるメカニズムで熱応力に変換されると 仮定する.

(1) 熱伝達

流体温度は単位断面積の熱伝達により内面要素に伝わり, 内面要素の温度 $\mathrm{T}_{\text {in }}$ を変化させる.

Fluid temperature Thermal stress

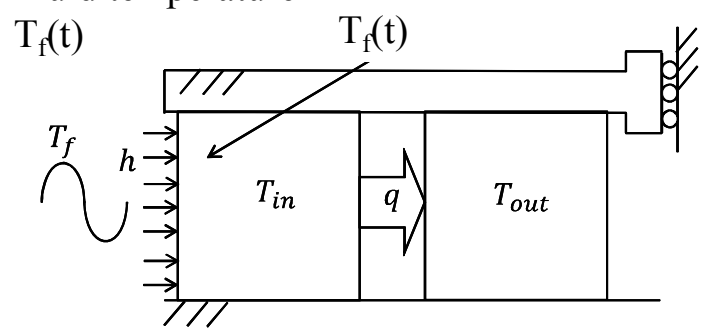

Fig.10 Thermal stress response of two degree model to fluid temperature. 
$h\left(T_{f}-T_{i n}\right)=c \rho T_{i n}^{\&}-q$

ここで, c:比熱, $\rho$ : 比重, $\mathrm{h}$ : 熱伝達率, $\mathrm{q}$ : 内面要素から外に出る熱流束である.

熱拡散内面要素の熱は材料の熱伝導特性により定まる熱流束 q によって外面要素に拡散していき外面要素の温度 Toutを変化させる.

$$
q=\lambda \frac{T_{\text {in }}-T_{\text {out }}}{L}=c \rho T_{\text {out }}^{\&}
$$

ここで, $\lambda:$ 熱伝導率である.

熱弾性内面要素と外面要素は, それぞれの温度に応じて線膨張係数 $\alpha$ で熱変形しようとするが, 同一板厚内で, 変形は相互に拘束し合うために内面要素に以下の熱応力が生じる.

$$
\sigma=-R E \alpha\left(T_{\text {in }}-T_{\text {out }}\right)
$$

ここで， $E$ : ヤング率， $\alpha$ : 線膨張係数， $R:$ ひずみの拘束率である.

式(1) (2) (3)をラプラス変換することにより, 流体温度に対する表面要素の応力の応答関数 $G(s)$ が, 流体から構 造表面への有効熱伝達関数 $H(s)$ と構造表面温度に対する構造表面の有効熱応力関数 $S(s)$ の積として表される.

$$
\begin{aligned}
& \frac{\sigma(s)}{T_{f}(s)}=\frac{T_{\text {in }}(s)}{T_{f}(s)} \cdot \frac{\sigma(s)}{T_{i n}(s)}=H(s) S(s)=G(s) \\
& H(s)=\frac{T_{i n}(s)}{T_{f}(s)}=\frac{1}{1+\tau_{f} s}, \tau_{f}=\frac{c \rho}{h}
\end{aligned}
$$

有効熱伝達関数 $H(s)$ は時定数 $\tau_{f}$ の一次遅れ伝達関数である.

$S(s)=\frac{\sigma(s)}{T_{\text {in }}(s)}=R E \alpha\left(1-\frac{1}{1+\tau_{s} s}\right), \tau_{s}=\frac{c \rho L}{\lambda}$

有効熱応力関数 $S(s)$ は時定数 $\tau_{s}$ の一次遅れ要素を含む伝達関数である.

式(4)(5)(6)から構造表面応力の周波数応答関数のゲインを求めると

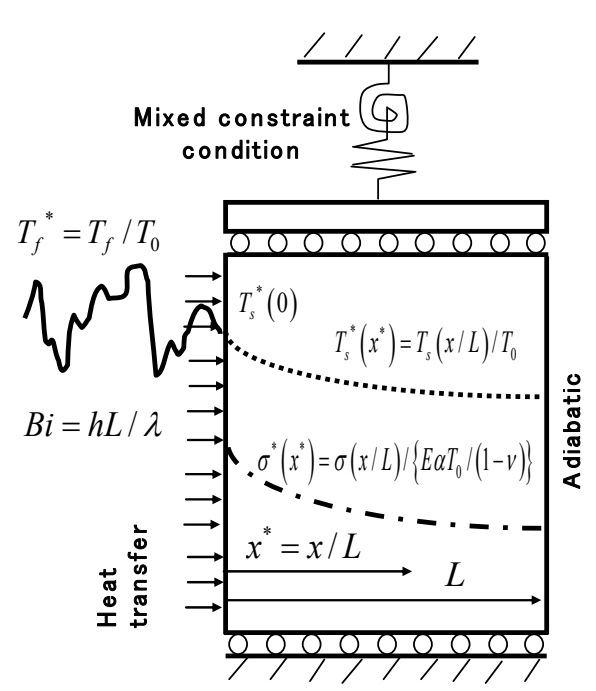

Theoretical 1D model

$$
\begin{aligned}
& \frac{\sigma^{*}(B i, j \omega)}{T_{f}^{*}(j \omega)}=G(B i, j \omega)=H(B i, j \omega) S(j \omega) \\
& \begin{array}{l}
\text { Frequency } \\
\text { Transfer Function }
\end{array}=\begin{array}{l}
\text { Effective heat } \\
\text { transfer function }
\end{array} \times \begin{array}{l}
\text { Effective thermal } \\
\text { stress function }
\end{array}
\end{aligned}
$$

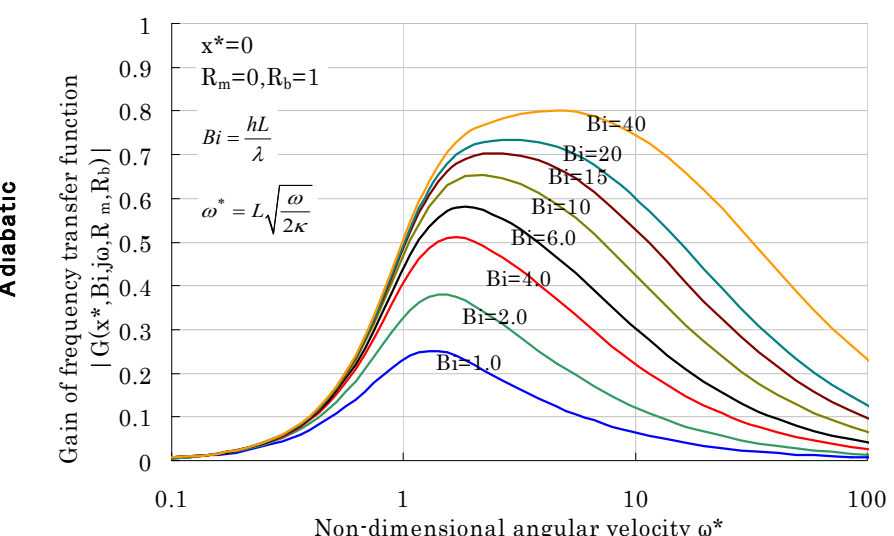

Fig.11 Thermal stress response of 1-D continuum model to fluid temperature. 
$|G(j \omega)|=R E \alpha \frac{1}{\sqrt{1+\omega^{2} \tau_{f}^{2}}} \cdot \frac{\omega \tau_{s}}{\sqrt{1+\omega^{2} \tau_{s}^{2}}}$

となる.式(7)から熱応力のゲインは

$\omega \rightarrow 0, \quad|G(j \omega)| \rightarrow 0$ および $\omega \rightarrow \infty, \quad|G(j \omega)| \rightarrow 0$.

となり, 低周波と高周波の両者で熱応力が小さくなる性質を定量的に説明することができる. また, 熱伝達係数, 拘束率，ヤング率，線膨張係数，板厚が大きくなると応力は増大し，熱伝導率が大きくなると減少する性質が導 かれる.

この考え方は，図 11 に示すように 1 次元連続体に拡張することができる．低周波側の減衰特性を示す構造物

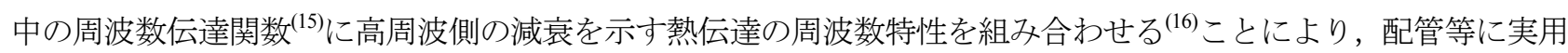
的な適用できる周波数伝達関数が得られる.

\section{4. 熱疲労き裂発生に関する研究}

\section{$4 \cdot 1$ BWR 炉水中低サイクル熱疲労}

流体中における熱疲労挙動を把握するため，沸騰水型軽水炉の模擬環境中で均一な熱ひずみを負荷できる熱疲 労試験装置を製作して, ステンレス鋼(SUS304,SUS316NG), 低合金鋼(SFVV2), および炭素鋼(STS410)の 4 鋼種 の熱疲労試験が行われている ${ }^{(17) \sim(20)}$. 具体的には，薄肉円筒試験片を取り囲むようなオートクレーブを製作し， その上下部にそれぞれ $90^{\circ}$ おきに 4 か所給水ノズルを配置し，中央部に $90^{\circ}$ おきに 4 か所の排水ノズルを配置 した. 給水ノズルからは高温水と低温水を交互に供給し, 試験片ゲージ部に均一な熱ひずみを発生させるという, いわゆる Manson-Coffin 型の熱疲労試験を行った．その結果の代表例として SUS304 鋼の試験結果を機械的な 疲労試験結果と比較して図 12 に示寸. 図において, 縦軸はひずみ振幅 $\varepsilon$ と縦弾性率 $E$ の積で求めた仮想弾性応力 振幅 $\mathrm{Sa}$ である. 機械的疲労試験は, 室温と $288^{\circ}$ 純水中および BWR 環境中で行った. 熱疲労では試験温度が室

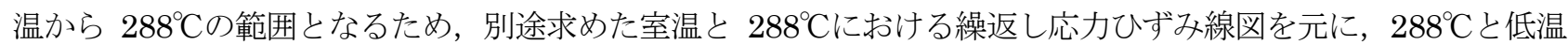
での平均ひずみ振幅から仮想応力振幅 $\mathrm{Sa}$ を求めた.

図 12 から分かるように，仮想応力振幅 Sa で整理すると，熱疲労き裂発生挙動は機械的疲労き裂発生挙動とよ く一致することが分かる.また, 図 12 から明らかなように大気中と溶存酸素濃度の異なる BWR 環境の影響も 認められない. SUS316NG 鋼でも全く同じ結果が得られている.

炭素鋼と低合金鋼においては，疲労寿命に及ぼすひずみ速度の影響が顕著である，しかしながら，高温水と低 温水を一定水量で交互に供する熱疲労試験においてはひずみ速度を制御することはできない，そのため，試験中 の応力変動から, 応力ひずみ曲線を元に, ひずみ履歴を求め, 最終的に 1 サイクル中の平均のひずみ速度を求め

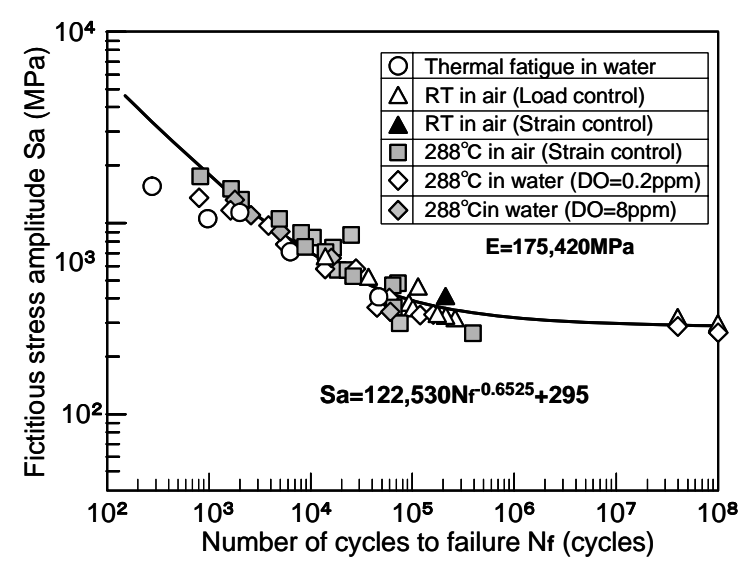

Fig.12 Comparison of thermal and mechanical fatigue strength in terms of fictitious stress amplitude.

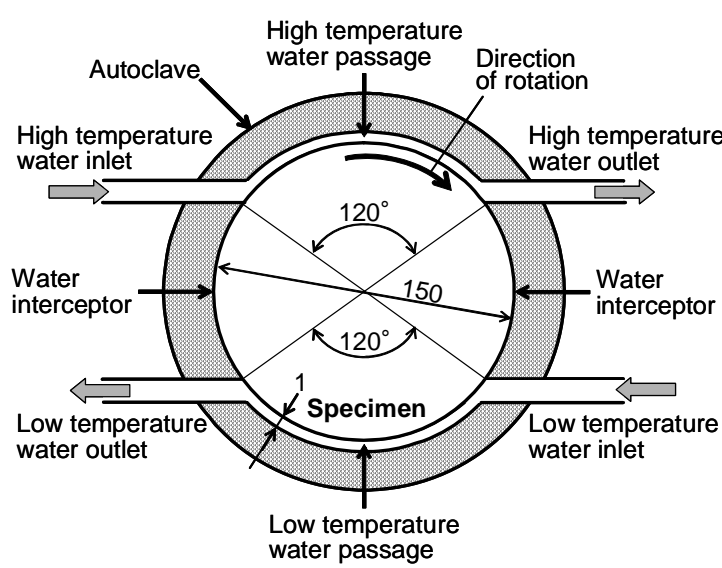

Fig.13 Schematic illustration of autoclave for thermal fatigue test in BWR water environment. 
た．その結果，樋口・飯田 ${ }^{(21)}$ が提案している，ひずみ速度，溶存酸素濃度，および温度を考慮した寿命減少係数 Fen により評価した結果, 熱疲労試験結果は機械的疲労試験結果とほぼ一致することが分かった ${ }^{(20)}$.

\section{$4 \cdot 2$ BWR 炉水中高サイクル熱疲労}

純水中にて数 $\mathrm{Hz}$ 程度の周波数で熱疲労試験を行える水中熱疲労試験装置のオートクレーブの構造概略を図 13 に示す ${ }^{(22)(23)}$. 試験装置には低温水と高温水を供給できる $8 \mathrm{MPa}$ の高圧ループが 2 系統あり, 図 13 のオートクレ ーブの上部のパスに高温水が，下部のパスに低温水が供給される.

オートクレーブの中心には直径 $150 \mathrm{~mm} ，$ 幅 $25 \mathrm{~mm}$ の円盤状の試験片を設置する．この試験片の外周部の一部 には実機構造体のラビリンスを模擬した幅 $1.6 \mathrm{~mm}$, 深さ $1.6 \mathrm{~mm}$ の溝を加工した. 試験片のオートクレーブ外部 に伸びた中心軸はインバータ制御の誘導型モータとカップリングを介して接続されており，所定の回転数で回転 させることが可能である.試験片が回転すると 1 回転毎に高温水と低温水に曝され, 回転同期の熱疲労を受ける. 純水と試験片表面との間の熱伝達率が高くなるように水室の半径方向寸法は $1 \mathrm{~mm}$ と小さくした．また，高温水 室と低温水室との間では高温水と低温水が混合しないようにするため，オートクレーブ内径と試験片外径を両者 が互いに接触しない限界まで近づけてある. なお, 純水の溶存酸素濃度は $8 \mathrm{ppm}$, 繰返し速度は $2.3 \mathrm{~Hz}$ と $4.6 \mathrm{~Hz}$ である.

なお，熱疲労試験に先立って，熱応力振幅評価に必要な熱伝達率を測定した結果，伝熱工学便覧などに示され ている数式で与えられる值よりも桁違いに高いことが明らかとなった ${ }^{(22) .}$

5 個の試験片のうち, 仮想応力振幅が $300 \mathrm{MPa}$ 以上で試験した 3 体には，ラビリンスのコーナー部から軸方向 にき裂が複数認められた。しかし，それより小さい仮想応力振幅で試験した 2 体の試験片ではき裂の発生は認め られなかった。

仮想応力振幅が $301 \mathrm{MPa}$ の試験体では約 $1.1 \times 10^{6}$ 回でき裂発生した. その後, 疲労試験を継続し, 直流ポテン シャル法でき裂深さを測定し, 約 $1.6 \times 10^{6}$ 回で電位差出力がほとんど変化しなくなったので約 $2 \times 10^{6}$ で疲労試験 を終了した. この試験体の平坦部を液体浸透探傷試験した結果を図 14 に示す. 軸方向き裂が近接して多数発生 しているのが認められる. 円盤状試験片を回転同期で熱疲労試験していること, および, 板厚が $25 \mathrm{~mm}$ と薄いた めに，周方向応力が卓越するために軸方向き裂がほとんどである.

図 15 に熱疲労試験結果を機械的疲労試験結果と比較して示す. 縦軸は仮想弾性応力振幅である. 機械的疲労 試験結果は, SUS304 鋼と SUS316NG 鋼の直径 $10 \mathrm{~mm}$ の丸棒中実型あるいは砂時計型試験片を室温大気中, $288^{\circ} \mathrm{C}$ 大気中, 並びに, $288^{\circ} \mathrm{C}$ 純水中で得られたものであり, 破損寿命を示している ${ }^{(23)}$. 機械的疲労試験結果を 仮想応力振幅 $\mathrm{Sa}$ で整理すると, 材質や試験雾囲気の影響は認められない. そこで, 機械的疲労試験結果を最小 自乗法により Stromeyer 近似した結果, 次式が得られた ${ }^{(24)}$.

$\mathrm{Sa}=122,530 \mathrm{~N}^{-0.6525}+295$

図 15 において○印と○印が熱疲労試験結果で，それぞれ繰返し周波数は $\mathrm{f}=2.33 \mathrm{~Hz}$ と $\mathrm{f}=4.66 \mathrm{~Hz}$ である。矢印

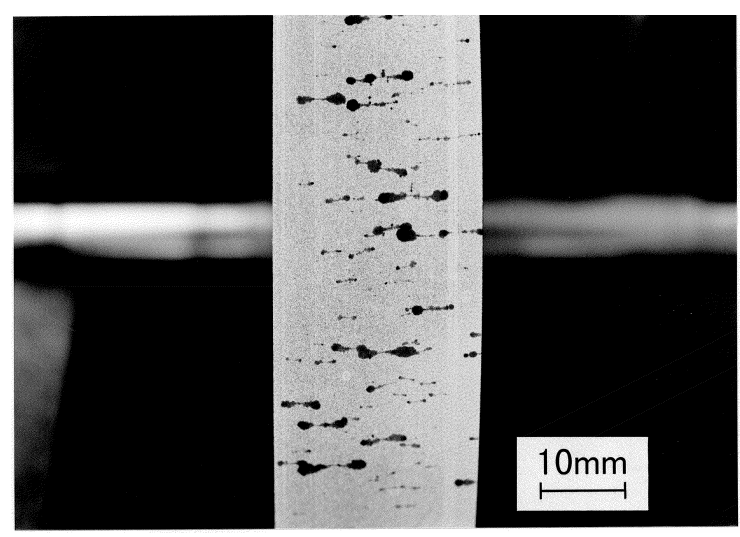

Fig.14 Penetration test result of thermal fatigue crack.

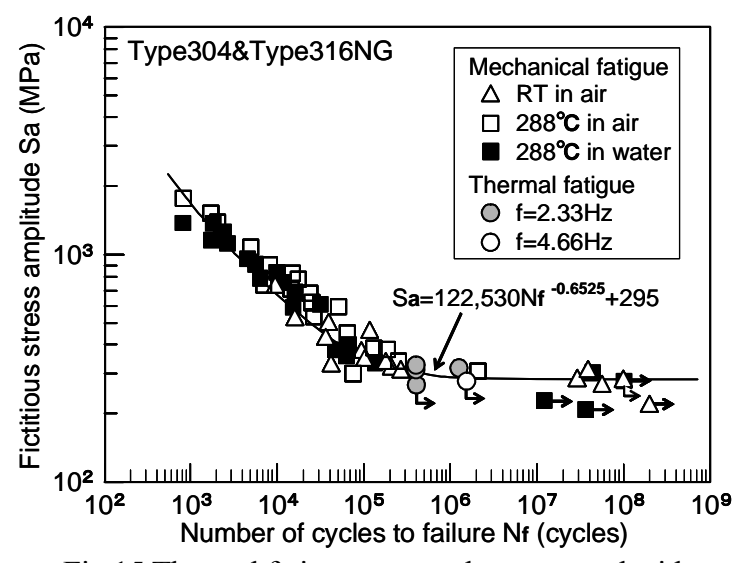

Fig. 15 Thermal fatigue test results compared with mechanical fatigue test results. 


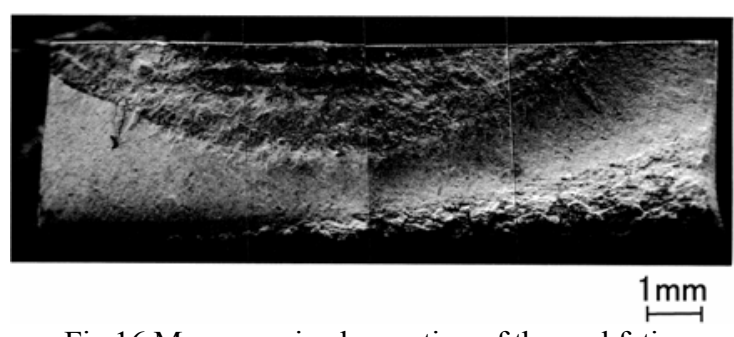

Fig.16 Macroscopic observation of thermal fatigue crack fracture surfaces.

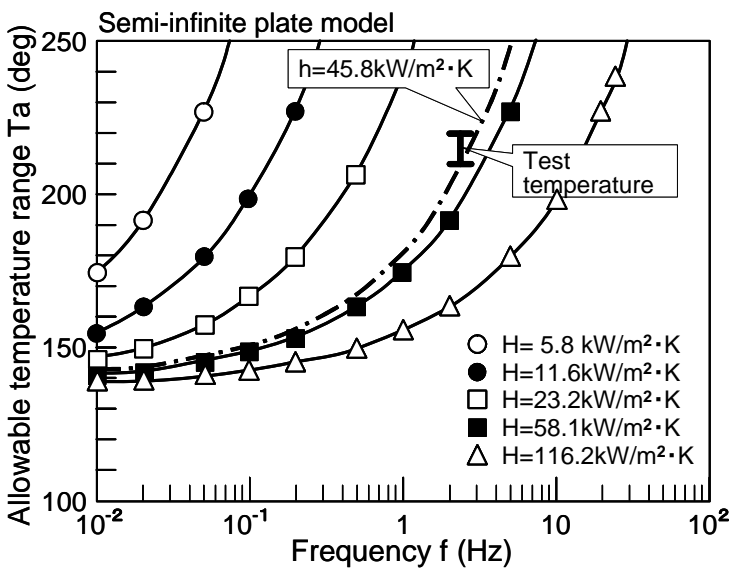

Fig.17 Allowable temperature range for thermal fatigue crack initiation.

を付けたものはき裂が発生しなかったものを示している. 図から分かるように, 熱疲労試験結果は Stromeyer 近 似した機械的疲労結果とよく一致する.

仮想応力振幅 Sa が 300MPa の試験片で表面き裂長さが最も長かった熱疲労破面の SEM 写真を図 16 に示す. 表面長さは $2 \mathrm{c}=11.7 \mathrm{~mm}$ で, き裂深さは $\mathrm{a}=1.86 \mathrm{~mm}$ であり, 形状は半円弧状である. いくつかの破面を観察した 結果, き裂長さが長いほど, アスペクト比 $\mathrm{a} / \mathrm{c}$ が小さいことが分かった. これは, 後述するように比較的高い周 波数の熱応力は深さ方向に分布を有し，表面では熱応力振幅が大きいのに対して，深いところでは熱応力振幅が 小さいため，表面方向は進展するが，深さ方向では停留するからである.

ラビリンス部でき裂深さが最大であったき裂について，破面形態のき裂梁さに伴う変化を調べたところ，き裂 深さが $\mathrm{a}=1.8 \sim 2.3 \mathrm{~mm}$ では粒内ファセットと粒界ファセットが混合した破面が続いた後, き裂先端近傍では粒内 ファセットとなり, ストライエーション状模様も認められた.

仮想応力振幅が $\mathrm{Sa} \geqq 295 \mathrm{MPa}$ となって熱疲労き裂が発生する流体の温度変動範囲を求めた結果を図 17 に示す. 図で横軸は温度変動周波数で, 縦軸は熱疲労き裂が発生する下限界の温度変動範囲であり, 金属表面の熱伝達率 $\mathrm{H}$ をパラメータとして求めたものである. 熱伝達率が低いほどき裂発生限界の温度変動範囲は高くなる. 本試験 の熱伝達率 $\mathrm{H}=45.8 \mathrm{~kW} / \mathrm{m}^{2} \mathrm{~K}$ に対する計算結果を一点鎖線で示すとともに, 熱疲労き裂が発生した温度範囲を示 したが, 試験結果は一点鎖線より僅かに上にあり，予測が良好であることが分かる. 熱伝達率が $\mathrm{H}=116.2 \mathrm{~kW} / \mathrm{m} 2 \mathrm{~K}$ と高く, 周波数が低くなると温度変動範囲は約 $135^{\circ} \mathrm{C}$ 飽和してくる.このことは SUS304 鋼や SUS316NG 鋼 では，平均応力がない状態で熱疲労き裂が発生するためには温度変動範囲は $135^{\circ} \mathrm{C}$ 以上が必要であることを示し ている(24).

\section{$4 \cdot 3$ ナトリウム中高サイクル熱疲労}

高サイクル熱疲労破損はナトリウム冷却高速炉でも問題となる破損様式(6) であることから, ナトリウム中の熱 疲労試験を行った ${ }^{(25)}$. 図 18 は日本原子力研開発機構の SPECTRA 熱疲労試験装置の試験体および周辺構造であ る. 試験部位は内径 $66.9 \mathrm{~mm}$ ，肉厚 $11.1 \mathrm{~mm}$, 長さ $1600 \mathrm{~mm}$ の SUS304 製の円筒である. 上流には高温と低温の ナトリウムを混合し，周方向温度がほぼ一定となるように整流する構造が取り付けてある．電磁ポンプにより流 量の時間変化を精密に制御した $550^{\circ} \mathrm{C}$ と $300^{\circ} \mathrm{C}$ のナトリウムを同時に流すことにより, 合計流量が一定（従って 熱伝達係数が一定） で, 平均 $425^{\circ} \mathrm{C}$, 最大振幅 $250^{\circ} \mathrm{C}$ の様々な温度変化パターンを有する熱荷重を発生させるこ とができる. 疲労試験に先立ち試験条件を確認するための温度試験を実施した. 温度計測は, ナトリウム中配管 内表面から流体側 $3 \mathrm{~mm}$ の位置でのナトリウム温度, 配管内表面, 配管肉厚内内表面から $5.5 \mathrm{~mm}$ の位置, 配管 外表面等をはじめとする試験体板厚方向に対し実施した。温度試験の目的はナトリウムの温度振幅と周期が適切 に制御できていることの確認，ならびに，配管内表面での温度応答を計測することによる熱伝達係数の同定の 2 つである. 図 19 はナトリウム中で計測した温度であり, 左から正弦波 $(0.05 \mathrm{~Hz}$, 他に $0.2 \mathrm{~Hz}, 0.5 \mathrm{~Hz}$ の実施), 2 波 


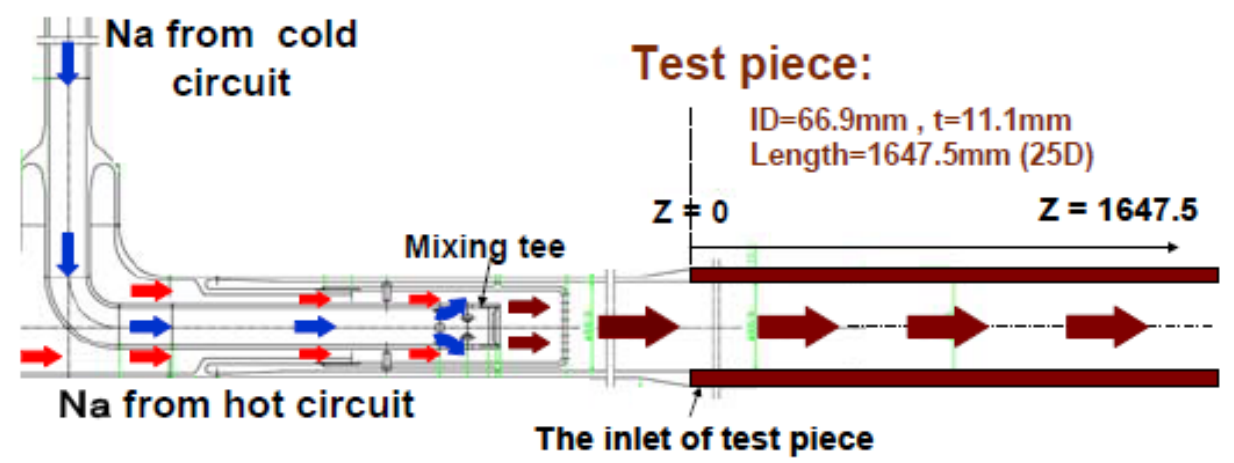

Fig.18 SPECTRA test section for sodium fatigue tests.

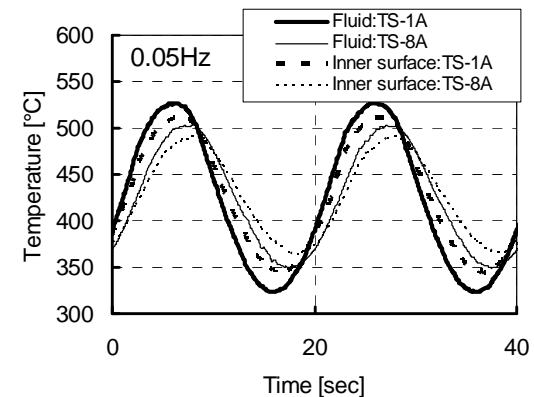

Single type: $0.05 \mathrm{~Hz}, 0.2 \mathrm{~Hz}, 0.5 \mathrm{~Hz}$

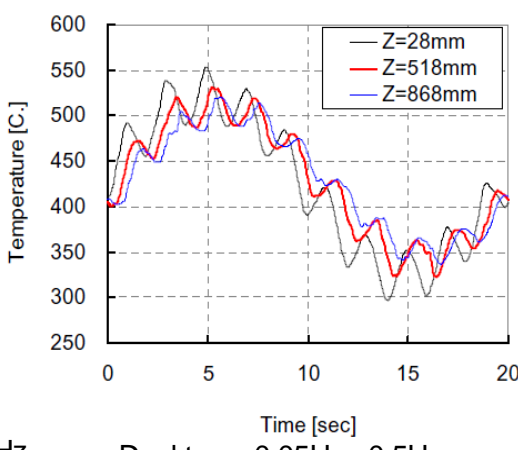

Dual type: $0.05 \mathrm{~Hz}+0.5 \mathrm{~Hz}$

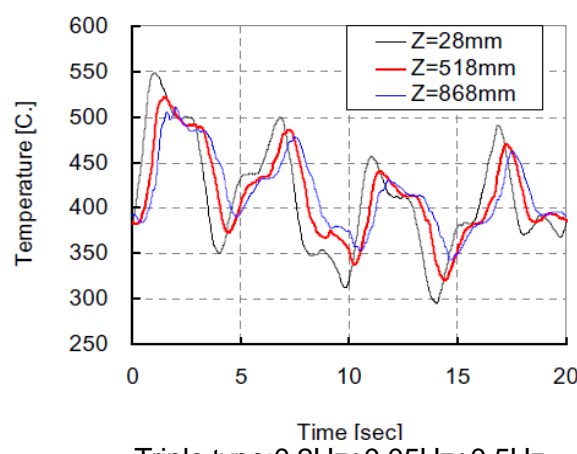

Triple type: $0.2 \mathrm{~Hz}+0.05 \mathrm{~Hz}+0.5 \mathrm{~Hz}$

Fig.19 Sodium temperature conditions.

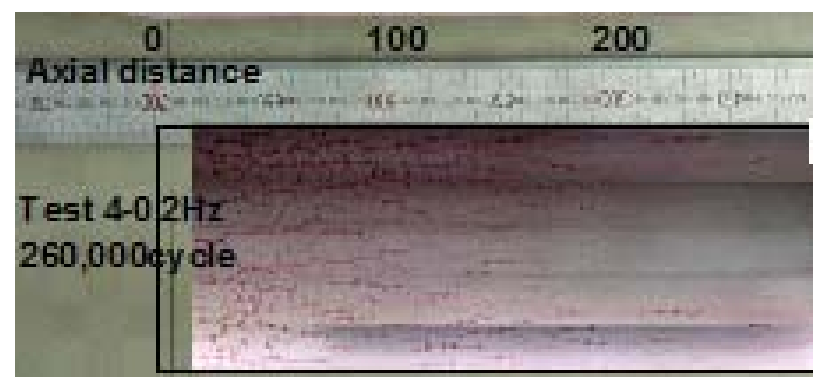

Fig.20 Observed cracks on the inner surfaces after thermal fatigue tests.

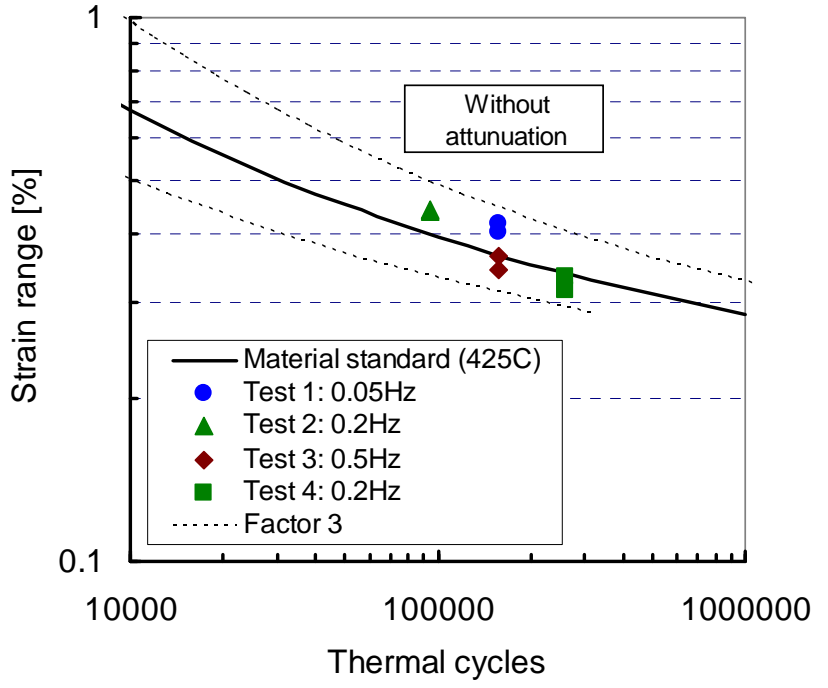

Fig.21 Fatigue damage evaluation results.

重畳 $(0.05 \mathrm{~Hz}+0.5 \mathrm{~Hz}), 3$ 波重畳 $(0.05 \mathrm{~Hz}+0.5 \mathrm{~Hz}+0.2 \mathrm{~Hz})$ の温度波形である.上流から下流に移動するに従い，熱 拡散によって徐々に振幅が小さくなっていく.

疲労試験では，き裂が貫通または外表面からの超音波探傷検査により試験体の荷重が減少する長手方向の途中 までき裂が発生した段階で負荷を終了し，試験体を切断してき裂の分布を計測した．図 20 に 73,810 サイクルの 2 波重畳条件，116,640 サイクルの 3 波重畳条件におけるき裂の分布を示寸. 長手方向で明確なき裂が観察され る境界位置をき裂発生点とした。

き裂発生評価において, 上記位置での温度計測試験から得られた, 流体温度と熱伝達係数を荷重条件とする。こ れに基づき, 3.2 節で説明した周波数伝達関数で熱応力を求め, 大気中で得られた平均疲労線図とマイナ一則に 
基づき疲労損傷係数を求めた，その結果を図 21 に示寸．熱忘力評価と疲労強度評価の両者を組み合わせた予測 精度が Factor of 3 以内に収まっていることが確認できた ${ }^{(26)}$.

\section{5．熱疲労き裂の進展と停留}

高周波数の熱疲労では発生する応力が分布するのは金属表面近傍であるため，周波数に依存して停留するもの と考えられる．き裂進展挙動を検討するには深さ方向の応力分布が必要である. 対象としたき裂はラビリンス形 状部の貫通き裂, 平滑部の貫通き裂と表面き裂の 3 種類である ${ }^{(24)}$. 熱伝達率を $\mathrm{H}=11.6 \mathrm{~kW} / \mathrm{m} 2 \mathrm{~K}$, 周波数を $\mathrm{f}=0.01$ $\sim 25 \mathrm{~Hz}$ ，温度変動幅を $250^{\circ} \mathrm{C}$ として平滑部表面近傍の熱応力分布を解析した ${ }^{(27)}$. 周波数 $\mathrm{f}=1 \sim 20 \mathrm{~Hz}$ のときの金 属表面近傍における熱応力分布を図 22 に示寸. 図は表面の応力が引張側で最大になったときの深さ方向の応力 分布であり，表面の応力が圧縮側で最大になったときには符号が逆転した対称の応力分布となる.

図 22 より応力分布は周波数に強く依存し, $\mathrm{f}=20 \mathrm{~Hz}$ では表面の応力は僅かに $60 \mathrm{MPa}$ で, 深さ $0.3 \mathrm{~mm}$ 程度で 圧縮応力になる. $\mathrm{f}=1 \mathrm{~Hz}$ でも表面の応力振幅は $210 \mathrm{MPa}$ で, 深さ約 $1.8 \mathrm{~mm}$ で圧縮応力に反転する. このように 変動周波数が比較的高い熱疲労においては，熱応力が発生する領域は金属表面から浅いことが分かる．また，こ の熱応力分布より熱疲労き裂は周波数に依存して，周波数が速いほど金属表面から浅いところで停留することが 予想される.

次に, 図 22 のような応力分布に対する応力拡大係数を求め, き裂進展評価を行った. き裂進展評価には線形 破壊力学を適用した. Buchalet ${ }^{(28)}$ は 3 次式で与えられる応力分布を有する半無限固体表面に存在する半円表 面き裂に対して応力拡大係数を定式化している. しかし, 熱応力分布を 3 次式で近似した場合, 近似が悪いこと が分かったそそこで，Buchalet の式を 5 次式に修正したものを用いた．即ち，応力分布が，

$$
\sigma=A_{0}+A_{1} x+A_{2} x^{2}+A_{3} x^{3}+A_{4} x^{4}+A_{5} x^{5}
$$

で与えられる場合，応力拡大係数は

$$
K=\sqrt{\pi \mathrm{a}}\left(0.688 \mathrm{~A}_{0}+0.522 \frac{2 \mathrm{a}}{\pi} \mathrm{A}_{1}+0.434 \frac{\mathrm{a}^{2}}{2} \mathrm{~A}_{2}+0.377 \frac{4 \mathrm{a}^{3}}{3 \pi} \mathrm{A}_{3}+0.336 \frac{\mathrm{a}^{4}}{4} \mathrm{~A}_{4}+0.304 \frac{8 \mathrm{a}^{5}}{5 \pi} \mathrm{A}_{5}\right)
$$

で与えられるものとした ${ }^{(24)}$.

熱応力分布を最小自乗法により式(9)のように5 次式で近似し, 式(10)により応力拡大係数範囲の分布を求めた. その結果の一例を図 23 に示寸. 周波数は $\mathrm{f}=0.1 \sim 1 \mathrm{~Hz}$ である. 応力拡大係数範囲はき裂が浅いときに急激に増大 し, ピーク值に達した後, 漸減する.

図 23 において応力拡大係数範囲が $\triangle \mathrm{K}=0 \mathrm{MPa} \sqrt{\mathrm{m}}$ となる深さで停留き裂深さを求めた. $\triangle \mathrm{K}=0 \mathrm{MPa} \sqrt{\mathrm{m}}$ で停留 き裂深さを求めた理由は, 疲労き裂進展下限界は温度変動範囲や平均応力の影響を受けるため, 最も保守的に評 価するためである．なお，疲労き裂進展下限界として SUS304 ステンレス鋼の室温大気中における值である $\triangle \mathrm{Kth}=4 \mathrm{MPa} \mathrm{Vm}^{(29)(30)}$ 用いても大差はない.

図 24 に停留き裂深さと水温変動周波数の関係を示す. 図中には半無限固体表面における半円表面き裂に加え

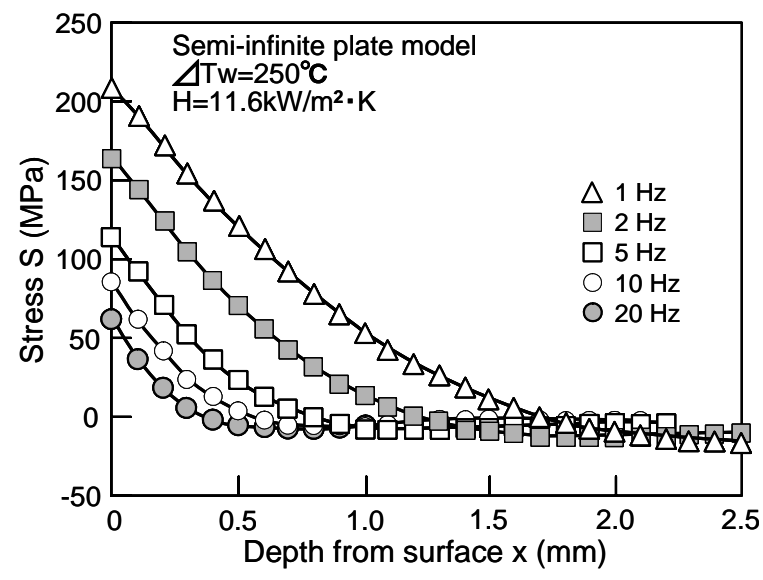

Fig.22 Thermal stress distributions near a metal surface $\left(\mathrm{H}=11.6 \mathrm{~kW} / \mathrm{m}^{2} \mathrm{~K}, \mathrm{f}=1 \sim 20 \mathrm{~Hz}\right)$.

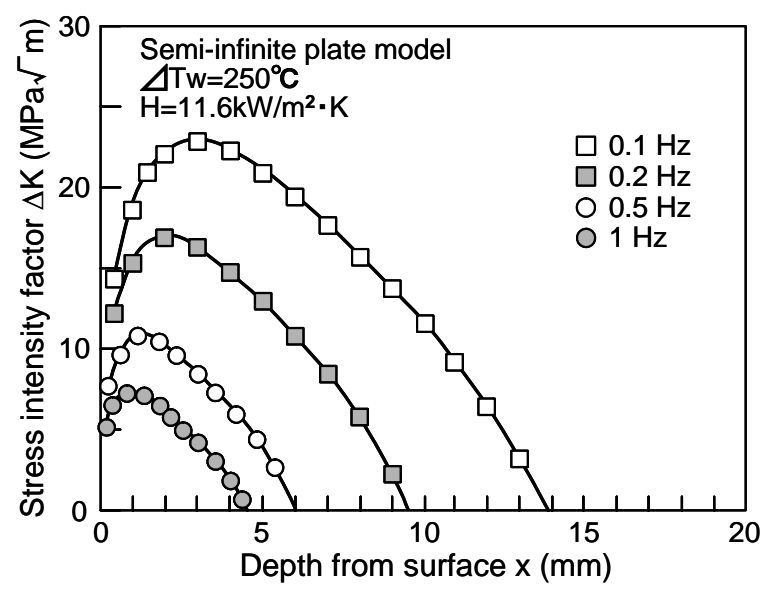

Fig.23 Stress intensity factor range distributions near a metal surface $\left(\mathrm{H}=11.6 \mathrm{~kW} / \mathrm{m}^{2}, \mathrm{f}=0.1 \sim 1 \mathrm{~Hz}\right)$. 


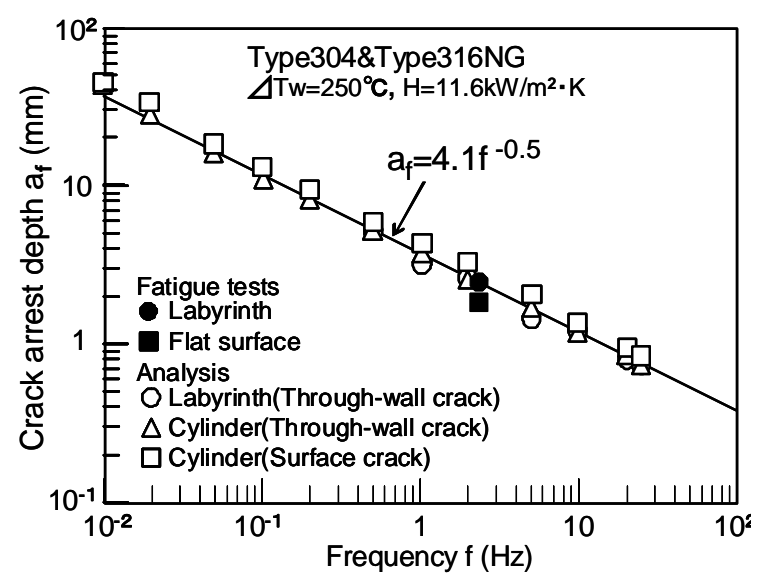

Fig.24 Relationship between crack arrest depth and frequency for semi-infinite plate model and labyrinth structure.

て, 貫通き裂(27)，ならびにポンプ軸シール部のラビリンス構造部における貫通き裂 ${ }^{(31)}$ の場合の解析結果も併せて 示した．半円表面き裂の停留深さがやや深い目であるが，ラビリンス部の貫通き裂，半無限固体表面の貫通き裂 と半円き裂のいずれに対してもほぼ同じ関係が成立する，そこで，停留き裂深さが周波数の平方根の逆数に比例 すると仮定して最小自乗法により両者の関係を求めた結果,

$$
\mathrm{a}_{\mathrm{f}}=4.1 \mathrm{f}^{-0.50}
$$

が得られた. 式(11)の結果を図 24 に実線で示す.

図 24 には平坦部表面の熱疲労き裂の停留深さを黒四角で, ラビリンス部の熱疲労き裂の停留深さを黒丸で示 した，平坦部の停留き裂深さは式(11)で与えられる停留深さよりもやや浅いがほぼ一致する，このように，熱疲 労試験による停留き裂深さは, 半無限固体表面近傍の定常熱伝達による熱忘力場における貫通き裂と半円表面き 裂，ならびに有限要素法によるラビリンス部の貫通き裂に対する解析結果と非常に良く一致する.

式(11)より水温変動周波数が $\mathrm{f}=1 \mathrm{~Hz}$ であれば，き裂は約 $4 \mathrm{~mm}$ で停留する．また，熱疲労き裂においては極端 に周波数が遅くない限り, き裂はある程度の深さで停留するため, 例え発生したとしても放置しても問題ないも のと思われる. なお, 図 24 を求めるに当たっては, き裂進展下限界応力拡大係数を便宜上 $\triangle \mathrm{Kth}=0 \mathrm{MPa} \sqrt{\mathrm{m}}$ とし ているため, 速い周波数のき裂に対しては深い目の結果を与えている. また, 熱疲労き裂は一般的には近接して 発生することが多いが，き裂が存在すると，き裂周辺の拘束が弱くなるため, き裂が周辺にない場合に比して応 力值が低下寸ることになるので, 式(11)で与えられる深さよりも浅いところでき裂は停留すると考えられる.

実機では図 2 と図 20 に示したように熱疲労き裂は亀甲状に発生することがある．その場合にはき裂が近接し ているため相互干渉により応力拡大係数が減少し, 単独のき裂よりも更に浅い状態で停留することがあり, 釜谷 らによって数值シミュレーションが行われている(32)．また，飯井らは各種条件下における熱疲労き裂の停留挙 動を解析している ${ }^{(33)-(35)}$.

\section{6. 原子炉構造物評価に対する適用}

\section{6・1 配管の高サイクル熱疲労評価指針の策定}

わが国では 1999 年に発生した敦賀 2 号機の再生熱交換器連結配管からの冷却材漏洩トラブルを契機に, 経済 産業省から通達が出され，基準化に向けた研究が開始された．日本機械学会に「配管の高サイクル熱疲労に関す る評価指針基準策定委員会」が設置され，2003 年に「配管の高サイクル熱疲労評価指針 JSME S017」が策定さ れた(4).

軽水炉においては，「不規則温度変動による高サイクル熱疲労」と「閉塞分岐管停留部の熱成層化による高サイ クル熱疲労」について, その発生頻度と対策の難しさから評価法整備の優先度が高いと判断され，これらの熱疲 労モードについて指針が主として試験研究に基づき整備された。この中で不規則温度変動による高サイクル熱疲 


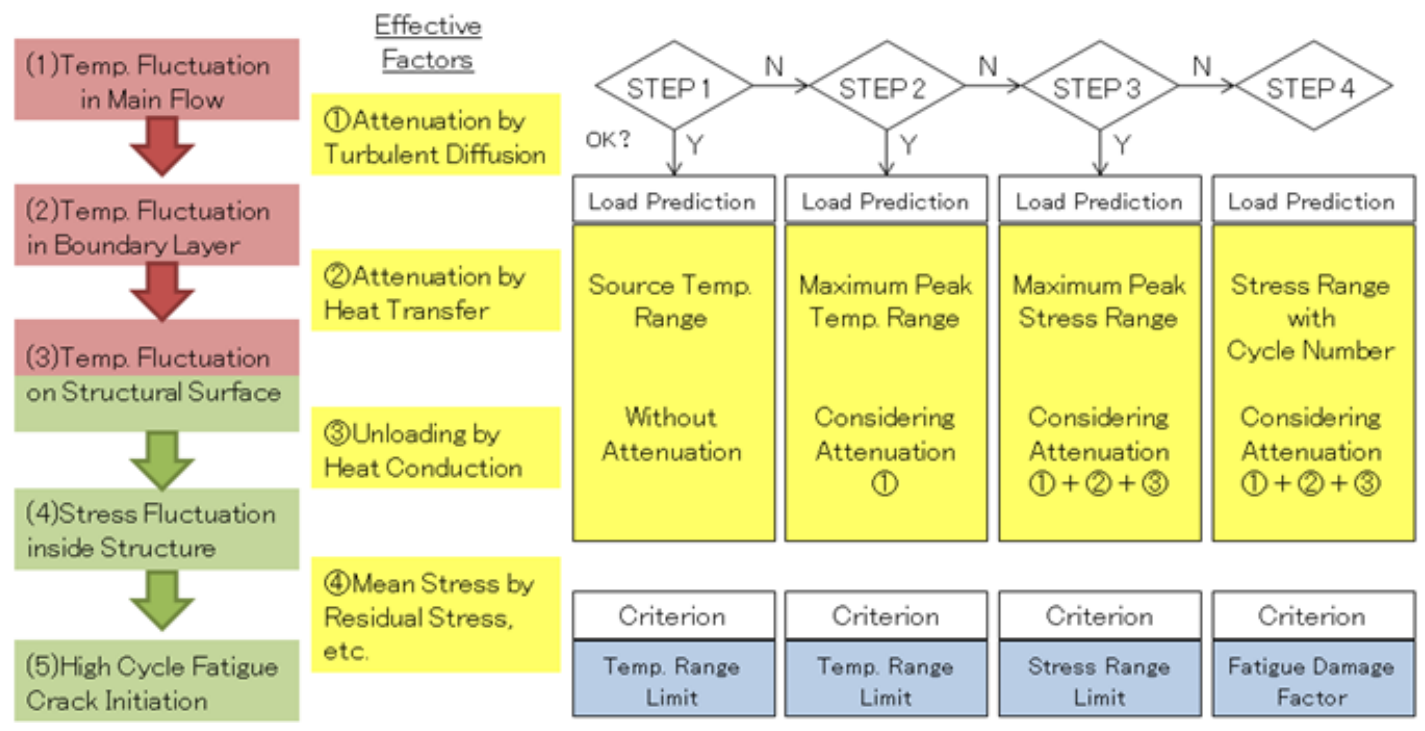

Fig.25 Fatigue evaluation procedure of the JSME guideline.

労」の評価概要を図 25 に示寸. 本指針の特徵は, 図 25 で説明した(1)から (3)の温度および応力変動の減衰要因を 段階的に考慮しながらスクリーニングを進めることである. 評価ステップ 1 では減衰要因を考慮せずに合流前の 流体温度差を，それによる発生応力が事実上疲労限以下とみなされる值で制限する. 実際には，高サイクル疲労 強度に関する各種制限值は, 原子炉機器の構造設計規格に記載の疲労線図から保守的に策定している. ここで 流体温度差および応力振幅の制限值に関しては本来疲労限に基づき策定されるべきものであるが，明瞭な限界が 存在しないステンレス鋼については, 繰り返し数 $10^{11}$ 回に相当する低サイクル側のデータからの外挿值を用いて いる. 評価ステップ 2 では減衰要因 (1) を考慮して流体合流時に発生する流体温度ゆらぎ幅を判定温度差と比較 する. 評価ステップ 3 では減衰要因(1)(2)(3)すべてを考慮に入れた場合の発生熱応力の上限を設計係数を用いて 評価し, 応力振幅を制限する. 評価ステップ 4 では減衰要因(1)(2)(3)の寸べてを考慮して発生熱応力と発生頻度 を評価し, 累積疲労損傷係数で制限する.また，疲労損傷係数による評価は，不規則波形からレインフロー波形 分解によって応力（温度）振幅と繰り返し数を求め, 材料の疲労曲線とマイナー則による累積疲労損傷係数を評 価する.

\section{$6 \cdot 2$ 高経年化対策強化基盤整備事業}

経済産業省原子力安全・保安院委託事業「高経年化対策強化基盤整備事業」において，高経年化対策に資する 技術情報基盤の整備が進められてきた ${ }^{(36)}$ 。この技術情報基盤の基本方針として, (1)推進側と規制側双方から活 用出来る中立的かつ客観的な内容 (組織横断), (2)流体, 構造, 材料といった各分野で共有でき, 全体を俯瞰でき る内容 (領域横断)，（3)ベテランの知識を若手に伝えられる内容（世代横断）を掲げており，情報を管理するため の階層構造を有するものがと考えられている.

現在我が国における規制評価は「高サイクル熱疲労に関する技術基準運用ガイドライン $(2000$ 年資源エネルギ 一庁)」および上記 JSME 指針に基づき行われている．しかし，JSME 指針発効後も温度成層が原因と考えられる 熱疲労破損を経験している(37) . また, JSME 指針に基づき破損事例の無い箇所も含めて設備対応を実施してき ている事業者側からは，海外に比較して厳しい制限等の合理化や概念に留まっている規定に対する強度評価法の 整備の要望が出されている．海外では 1998 年のCivaux 配管の高サイクル熱疲労による破損経験後(38)，フラン スで大規模な研究開発を展開中であり, それに関連して OECD/NEA で国際ベンチマーク解析が実施されている (39). また, 規制側は上記指針が安全裕度を持つことを検証し, 適正な運用がなされることを監視する必要がある. 以上の背景から, 原子力プラントの配管における熱疲労に関する客観性を有する事実の記載と, 専門外の方にも 分かり易い教科書的な現象解説を重視した, 技術情報基盤の整備が進められている. その中では, 数值解析手法 の適用研究やJSME 指針の裕度の明確化，その手法の提案等が課題として挙がっている. 


\section{7. 結 言}

原子力プラントにおける熱疲労事象の代表例は，配管の分岐部や合流部における高温水と低温水の混合によっ て生じる高サイクル熱疲労である．熱疲労の課題は，熱流動と構造に関わる複雑なものであることが認識され， 両分野の専門家の協力により，配管分岐部を対象とした熱荷重評価から疲労損傷評価までを含む幅広い研究開発 と実機への適用検討が行われた。

（1）熱荷重評価法

熱荷重の原因となる熱流動評価では，試験に基づく温度変動メカニズムの解明を通して，流動パターン分類や 温度ゆらぎの周波数特性を評価する線図を開発した. また, CFD の適用性研究が行われ，LES モデルにより実 用的な解析を行える見通しが得られつつある. 今後は, 検証と妥当性確認 $(V \& V)$ を含む数值シミュレーション手 法の整備が期待される.

熱応力評価では, 数值シミュレーション手法の研究と, メカニズム分析に基づく機構論的モデルの開発を行っ た. 前者では, CFD コードと構造解析コードを組み合わせた手法を検討した. ここでの課題は, 流体温度の構造 への受け渡しであり, 誤差の大きい熱伝達係数の評価精度向上と, 熱伝達係数を使用しない流体構造熱連成解析 法の開発が今度の課題である．機構モデルでは，高周波で減衰する熱伝達特性と低周波で減衰し易い熱応力特性 に着目した 1 次元の周波数伝達関数による熱荷重評価法を開発した. 今後は多次元温度分布を有する構造への適 用範囲拡大が期待される.

(2) 疲労損傷評価

高温水と低温水が不規則に混合して発生する高サイクル熱疲労表面き裂の発生, 進展, 停留挙動に関するこれ までの研究について紹介した．環境中低サイクル熱疲労試験およびナトリウム中高サイクル熱疲労試験により, 仮想応力振幅, すなわち, ひずみ振幅で整理すると, 熱疲労き裂の発生挙動は機械的疲労挙動とよく一致するこ とを確認した．次に，環境中の高サイクル熱疲労試験においても，同様のことを確認した．なお，SUS304およ びSUS316NG ステンレス鋼においては，約 $135^{\circ} \mathrm{C}$ 流体温度差がなければ熱疲労き裂は発生しない，実機にお いて, それよりも小さい温度差でき裂が発生しているのは, 応力集中や残留応力の影響があるものと推定される.

比較的高周波数の熱疲労においては, 熱応力は温度変動を受ける材料表面近傍に限定されるため, 熱疲労き裂は 停留することが予想される. 応力拡大係数の分布を求め, き裂進展下限界を $\Delta \mathrm{Kth}=0 \mathrm{MPa} \sqrt{\mathrm{m}}$ として停留き裂深 さを求めると, 停留き裂深さは周波数の平方根の逆数に比例し, 周波数 $\mathrm{f}=1 \mathrm{~Hz}$ では約 $4 \mathrm{~mm}$ で停留する. 従って, 比較的周波数の高い熱疲労き裂については放置しておいても板厚を貫通することはない.

(3) 実機適用検討

$\mathrm{T}$ 字管の「不規則温度変動による高サイクル熱疲労」に関寸る研究は一定程度進み, 指針の整備まで進んだが, 今後は，指針に含まれる様々な影響因子の中から支配的因子に着目し，簡便で適正が裕度を有する評価法の開発 が期待される．熱成層やその他に分類した熱疲労においては，流体の流れが複雑で，メカニズムの解明と熱応力 評価に必須の熱伝達率等の評価技術の高度化が必要である. それらの解析技術の開発と併せて, 複雑なメカニズ ムの知識べース化を進め，それを基に実用的手法の整備を進めるべきと考える.

\section{参考文献}

(1) Faidy,C." "Thermal fatigue in mixing areas: Status and justification of French assessment method",3rd International conference on fatigue of reactor components, EPRI-US NRC-OECD NEA, Seville, Spain (2004) .

（2）奥田恭令，“軽水型原子力発電所の熱疲労による配管の損傷の分析”, 原子力 eye, Vol.47, No.5 (2001), pp.60-64.

(3) 奥田恭令, “軽水炉の熱疲労による不具合事象の分析”, INSS Journal, Vol..7 (2000), pp.83-99.

(4) 配管の高サイクル熱疲労に関する評価指針，S017-2003 (2003), 日本機械学会.

(5) 原子力発電所における事故報告書「敦賀 2 号機の再生熱交換器連結配管における 1 次系泠却材の漏洩について」, (1999), 日本原子力発電.

(6) Validation of fast reactor thermomechanical and thermohydraulic codes, TECDOC-1318, (2002), IAEA.

(7) Experience with Thermal Fatigue in LWR Piping Caused by Mixing and Stratification, Specialists Meeting Proceedings Paris, France 8-10 June 1998, (1998), ISPN/OECD-NEA/WANO. 
(8)「経年変化と熱流動」特別専門委員会編, 原子力プラントの経年変化と熱流動, (1999), pp.80-131, 日本原子力学会.

(9) 河村勉，他, “同径 T 字合流配管におけるサーマルストライピング試験（第 1 報，流れの可視化と流体温度ゆらぎ特 性）”，日本機械学会論文集 B 編, Vol.69, No.682 (2003), pp.1445-1452.

(10) Igarashi M. et al., "Experimental Study on Fluid Mixing for Evaluation of Thermal Striping in T-pipe junction," 10th International Conference on Nuclear Engineering, ICONE10-22255, (2002).

(11) Igarashi M. et al., "Study on Fluid Temperature Fluctuation and Transfer to Wall in a Mixing Tee," $11^{\text {th }}$ International Conference on Nuclear Engineering, ICONE11-36299, (2003).

(12) 福島直哉, 深潟康二, 笠木伸英, “T 形合流部における乱流混合の直接数值シミュレーション”, 第 39 回日本伝熱 シンポジウム, (2002), pp.39-40.

(13) Report of the OECD/NEA-Vattenfall T-Junction Benchmark exercise, NEA/CSNI/R (2011), OECD/NEA.

(14) Akira NAKAMURA, Hiroshi IKEDA, Shaoxiang QIAN, Masaaki TANAKA and Naoto KASAHARA, "Benchmark Simulation of Temperature Fluctuation using CFD for the evaluation of the thermal load in a T-junction Pipe", NTHAS7, N7P-0011, (2010).

(15) Jones, I., "The effect of various constraint conditions in the frequency response model of thermal striping", Fatigue Fract. Engng. Mater. Struct. Vol.18, No.4 (1995), pp.489-502.

(16) Kasahara,N.,Takasho,H. and Yacumpai,A., "Structural response function approach for evaluation of thermal striping phenomena”, Nuc. Eng. Des., Vol.212, (2002), pp.281-292.

(17) Hayashi, M., Enomoto, K., Saito, T., and Miyagawa, T., "Development of thermal fatigue testing apparatus with BWR water environment and thermal fatigue strength of austenitic stainless steels", Nuclear Engineering Design, Vol.184, (1998), pp.113-122.

(18) Hayashi, M., "Thermal fatigue strength of type 304 stainless steel in simulated BWR environment", Nuclear Engineering Design, Vol.184, (1998), pp.135-144.

(19) Hayashi, M., "Thermal fatigue behavior of thin-walled cylindrical carbon steel specimens in simulated BWR environment", Nuclear Engineering Design, Vol.184, (1998), pp.123-133.

(20) 林眞琴，“低合金鋼 SFVV2 の純水中における熱疲労強度”，日本機械学会論文集 A 編，Vol.64, No.625 (1998), pp.2346-2352.

(21) Higuchi, M., Iida, K. and Asada, Y., "Effect of strain rate change on fatigue life of carbon steel in high-temperature water", STP 1298, ASTM, (1997), pp.216-231.

(22) 平野明彦，林眞琴，武原秀俊，田中賢彰，飯倉俊彦，“純水中高サイクル熱疲労試験装置の開発と回転二重円筒隙 間部の熱伝達率測定”，日本機械学会論文集 A 編, Vol.64, No.622 (1998), pp.1468-1474.

(23) 平野明彦, 林眞琴, 武原秀俊, 田中賢彰, “オーステナイト系ステンレス鋼 SUS304 の純水中における高サイクル 熱疲労き裂発生挙動”, 日本機械学会論文集 A 編, Vol.65, No.639 (1999), pp.2287-2292.

(24) 林眞琴, 平野明彦, “BWR 模擬環境中における高サイクル熱疲労表面き裂の発生・進展・停留挙動”, 日本機械学 会論文集 A 編, Vol.69, No.685 (2003), pp.1353-1359.

(25) Nobuchika KAWASAKI, Sumio KOBAYASHI, Shinichi HASEBE, and Naoto KASAHARA, "SPECTRA thermal fatigue tests under frequency controlled fluid temperature variation -transient temperature measurement tests-“, ASME, PVP2006-ICPVT11-93548, (2006).

(26) Nobuchika KAWASAKI, Sumio KOBAYASHI, Shinichi HASEBE, and Naoto KASAHARA, "SPECTRA thermal fatigue tests under frequency controlled fluid temperature variation - Superposed Sinusoidal Temperature Fluctuations-“, ASME, PVP2008-61225, (2008)

(27) 林眞琴, “半無限平板モデルにおける高サイクル熱疲労き裂の発生と停留挙動”, 日本機械学会論文集 A 編, Vol.64, No.619 (1998), pp.573-578.

(28) Buchalet, C. B. and Bamford, W. H., "Mechanics of Crack Growth”, ASTM STP, Vol.590, (1976), pp.385-402.

(29) 宇佐美三郎・志田茂, “疲労き裂進展限界值に及ぼす環境，応力比および久陥寸法の影響”，材料, Vol.31 (1982), pp.493-499. 
（30）小林英男, 朴卿東, 合金鋼, “炭素鋼の中・高温疲労き裂進展下限界特性に及ぼす酸化被膜の影響”, 圧力技術, Vol.30 (1992), pp.14-21.

(31) 林眞琴, 田中信彦, 猪木健, “水温変動を受けるラビリンス構造における熱疲労き裂の発生と停留挙動”, 日本機械 学会論文集 A 編, Vol.68, No.670 (2002), pp.969-976.

（32）釜谷昌幸，S. Amine, S. Taheri，“熱疲労荷重下における亀甲状き裂の発生要因と影響”，日本機械学会論文集 A 編， Vol.75, No.751 (2009), pp.343-352.

(33) 飯井俊行, 酒井信介, “厚肉円筒の熱応力下の疲労き裂停留（第 1 報, 片側き裂板による予備検討）”, 日本機械学 会論文集 A 編, Vol.63, No.606 (1997), pp.275-280.

(34) 飯井俊行, 酒井信介, “厚肉円筒の熱応力下の疲労き裂停留（第 2 報，円筒と片側き裂板）”，日本機械学会論文集 A 編, Vol.63, No.606 (1997), pp.281-285.

(35) 飯井俊行, 細田誠, 渡邊勝彦, “繰り返し熱衝撃下円筒内表面環状き裂の停留深さ”, 日本機械学会論文集 A 編, Vol.67, No.661 (2001), pp.1535-1541.

(36) 経済産業省原子力安全・保安院委託事業「高経年化対策強化基盤整備事業」http://nisaplm.jp/html/index.html

(37) 九州電力株玄海原子力発電所 2 号機の定期検査中に発見された余剩抽出入水系統取出配管のひび割れの原因と対 策に関わる九州電力株からの報告及び検査結果について, (2007), 原子力安全・保安院.

(38) Faidy, C., "High cycle thermal fatigue: lessons learned from Civaux event", 2nd International Conference on Fatigue of Reactor Components, Snowbird, Utah, July 29-31, (2002)

(39) Chapuliot, et. al., "OECD benchmark on thermal fatigue problem: Synthesis of the benchmak",3rd International conference on fatigue of reactor components, EPRI-US NRC-OECD NEA, 2004, Seville, Spain,29-31, (2002) 